\title{
語音聴力によるパッチテストの評価
}

\author{
小林 謙・相原 康孝・佐久間文子 \\ 石田 祐子・上村 敏夫・神尾 友和

\section{Prosthesis Test for Chronic Otitis Media with Perforation ; Evaluation by Speech Hearing Test}

\author{
Yuzuru Kobayashi, Yasutaka Aihara, Ayako Sakuma, \\ Yuko Ishida, Toshio Kamimura and Tomokazu Kamio \\ (Kamio Memorial Hospital)
}

Pure tone hearing level and speech reception threshold in the presence of a prosthesis were investigated in 80 ears with chronic otitis media with perforation to clarify the usefulness of the assessment of speech hearing in evaluating the prosthesis test. The tests were repeated after tympanoplasty in the same patients.

In 38 ears with no abnormalities of the ossicular chain, both the pure tone hearing level and the speech reception threshold were improved by the prosthesis. In 31 ears with fixation of the ossicular chain, the pure tone hearing level at low to middle frequencies was improved by the prosthesis, but the speech reception threshold did not improve. In 11 ears with dislocation of the ossicular chain, both the pure tone hearing level and the speech reception threshold did not improve with the prosthesis.

Both the hearing level and the speech reception threshold improved in ears with no abnormalities after tympanoplasty. They also improved after tympanoplasty in ears with dislocation of the ossicular chain. In ears with ossicular fixation, hearing levels at low frequencies improved after the operation, but the speech reception threshold did not improve.

These results suggest that the prosthesis test should be performed with the assessment of both the pure tone hearing level and speech hearing.

Key words: prosthesis test, speech hearing test, tympanoplasty

\section{はじめに}

慢性穿孔性中耳炎の手術例に対するパッチテ ストは術前に伝音連鎖の状態を知ることができ る検查法として，また手術後の聴力変化をある 程度知ることができる検査法として広く行われ ている1)2)。従来, パッチテストの判定には純 音聴力検查を用い, 語音聴力検査を利用するこ
とは少ない。しかし，鼓室形成術後の純音聴力 と語音聴力の変化が必ずしも一致しない場合が あり3)4, パッチテストに扔いても語音聴力に よる判定が純音聴力のそれと異なる結果となる 可能性もある. そこで，今回パッチテストの判 定を純音聴力検査と語音聴力検査とで行い, 両 者を比較検討した。 


\section{対象と方法}

平成元年 1 月より 12 月までに神尾記念病院に て鼓室形成術を施行した症例のらち, 術前にパ ッチテストを行いその前後で純音聴力検査なら びに語音聴力検査を行い得た 80 耳を対象とした. 対象とした 80 耳のらち，耳小骨連鎖に異常がな かった症例 (連鎖正常群)が38耳, 耳小骨連鎖に 固着病変のあった症例 (固着群)が 31 耳拉よび耳 小骨連鎖に離断の認められた症例(離断群)が11 耳であった. 術式の内訳を病変別に表 1 に示し た。 パッチには圧迫したジェルフォームを生理 食塩水で浸したものを用いた。 パッチ前後で純 音聴力検査, 語音聴力検査を行い, 両者を比較 検討した。また術後 1 年目の純音括よび語音聴 力検査を行い，パッチテストの結果と比較検討 した．語音聴力検査の指標として，語音聴取閾 值を用いた。

\section{結 果}

連鎖正常群，固着群打よび離断群それぞれの 術前の周波数別気導聴力レベルの平均値を図 1 に示した．術前の気導聴力レベルは連鎖正常群 $30 \sim 40 \mathrm{~dB}$, 固着群汪淁 $50 \mathrm{~dB}$, 離断群 $60 \sim 70$ $\mathrm{dB}$ と順に上昇した。

各群のパッチ前後の周波数別気導聴カレベル の平均値と標準偏差を図 2 に, 語音聴取閾値の 平均值と標準偏差を表 2 に示した。連鎖正常群 ではパッチにより $8 \mathrm{kHz}$ を除くすべての周波 数で気導聴カレベルが有意に改善した (t-test,

表 1 連鎖正常群, 固着群, 離断群それぞれの術 式の内訳. コルメラ而型はアブミ骨にコル メラを立てる術式を，コルメラ型はアブミ 骨の上部構造が消失している症例にアブミ 骨底板に直接コルメラを立てる術式であ る.

\begin{tabular}{l|c|c|c|c}
\hline \hline & I 型手術 & $\begin{array}{c}\text { コルメラ } \\
\text { III型 }\end{array}$ & コルメラ型 & \\
\hline 連鎖正常群 & 38 & 0 & 0 & 38 \\
固 着 群 & 25 & 5 & 1 & 31 \\
離 断 群 & 0 & 9 & 2 & 11 \\
\hline & 63 & 14 & 3 & 80
\end{tabular}

$\mathrm{p}<0.01$ 以下の検定も同様). 固着群では $1 \mathrm{kHz}$ を除く低中音域で気導聴力レベルが有意に改善 したが，高音域では改善を認めなかった。離断 群ではパッチ後聴力レベルが改善する傾向を認 めたが，有意な変化ではなかった。語音聴取閾 值は連鎖正常群ではパッチ後有意に改善したが， 固着群执よび離断群では有意な変化は認められ なかった。

連鎖正常群，固着群および離断群の術前後の 周波数別気導聴力レベルの平均值と標準偏差を 図 3 に, 語音聴取閾值の平均值と標準偏差を表

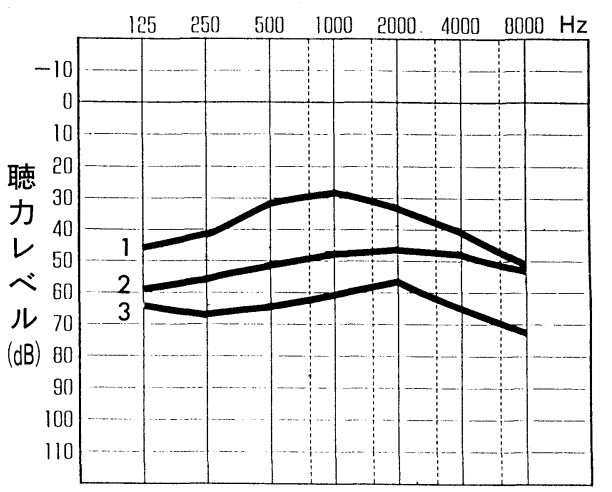

周 波 数 $\mathrm{Hz}$

図 1 連鎖正常群 (1), 固着群 (2)扣よび離断群 (3) それぞれの術前に括汁る周波数別気導 聴力レベルの平均値.

表 2 各群のパッチ前後の語音聴取閾値の平均値 と標準偏差

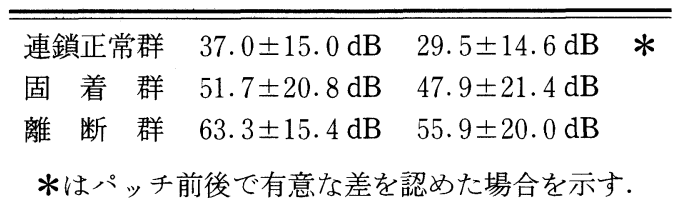

表 3 各群の術前後の語音聴取閾値の平均值と 標準偏差

\begin{tabular}{llll}
\hline \hline 連鎖正常群 & $37.3 \pm 15.1 \mathrm{~dB}$ & $30.1 \pm 13.5 \mathrm{~dB}$ & $*$ \\
固 着 群 & $49.2 \pm 20.6 \mathrm{~dB}$ & $44.1 \pm 19.5 \mathrm{~dB}$ & \\
離 断 群 & $69.5 \pm 16.6 \mathrm{~dB}$ & $43.0 \pm 22.7 \mathrm{~dB}$ & $*$ \\
*は術前後で有意な差を認めた場合を示す.
\end{tabular}


3 に示した。連鎖正常群では $1 \mathrm{kHz}, 4 \mathrm{kHz}$ 打 よび $8 \mathrm{kHz}$ を除く周波数で術後に気導聴力レ ベルの有意な改善を認めた。固着群では 125 $\mathrm{Hz} ， \quad 250 \mathrm{~Hz}$ 抢よび $2 \mathrm{kHz}$ の気導聴力レベルは 術後有意に改善したが，その他の周波数では有 意な変化は認められなかった。一方，離断群で は $125 \mathrm{~Hz}$ 打よび $8 \mathrm{kHz}$ を除く周波数で聴力レ ベルの有意な改善が認められた。語音聴取閾値 では連鎖正常群と離断群では術後有意な改善を 認めたが，固着群では語音聴取閾値の改善の傾 向を認めたものの有意な変化はなかった。

\section{考察}

今回の検討では，耳小骨に固着病変がある症 例でもパッチテストにより低中音域の純音聴力 レベルが改善した，さらに，離断病変のある症 例では聴力レベルに有意な変化は認められなか ったが，いわゆるIII型パッチでは離断病変でも 聴力レベルが改善する可能性もある．杉山ら5) もパッチで改善しても約半数に耳小骨連鎖の異 常があることを報告しており，純音聴力レベル のみでパッチテストを評価することには注意を 要する。一方，語音聴取閾值は固着あるいは離 断病変のある症例ではパッチテストによって有 意な改善が認められず，純音聴力レベルと語音

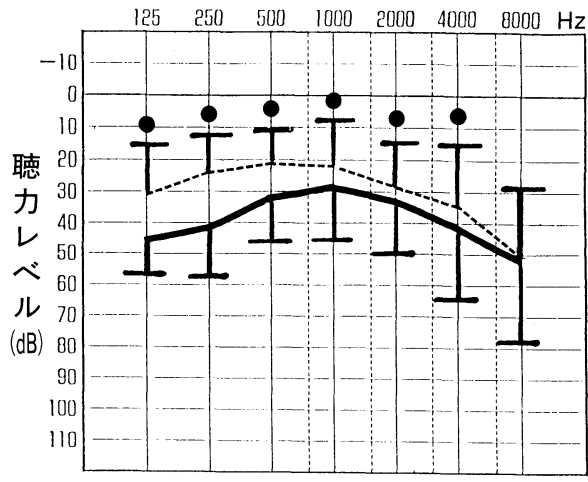

周 波数 $\mathrm{Hz}$

A. 連鎖正常群



周 波 数 $\mathrm{Hz}$

B. 固着群

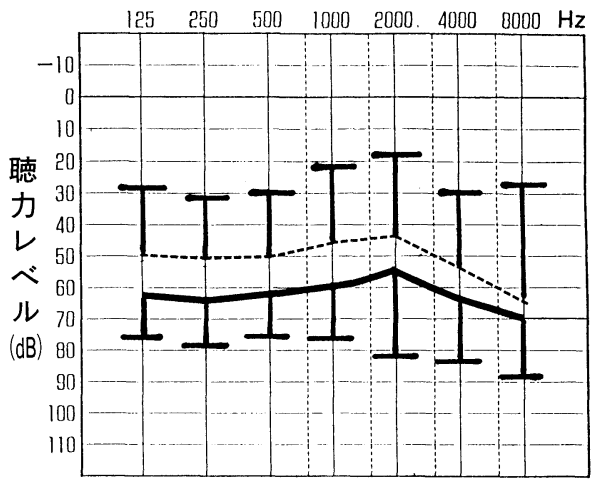

周 波 数 $\mathrm{Hz}$

C. 離断群

図 2 各群のパッチ前後の周波数別気導聴力レベルの平均值と標準偏差

実線はパッチ前，点線はパッチ後を示す。・はパッチ前後で有意な差を認めた場合を示す. 
聴取閾値を組み合わせることにより耳小骨の病 変をより的確に知ることができると推測される.

今回の検討からは, 術前の気導聴力レベルが $30 \sim 40 \mathrm{~dB}$ であって，パッチテストにより聴力 レベル，語音聴取閾値ともに改善する場合には 耳小骨連鎖には異常がないと考えてよいと思わ れる.しかし，パッチテストによって気導聴力 レベルが改善しても語音聴取閾値が改善しない 場合には耳小骨に固着病変が，さらに術前の気 導聴力レベルが $60 〜 70 \mathrm{~dB}$ 以上であってパッチ テストによって聴力レベル，語音聴取閾値とも に改善しない場合には離断病変の可能性が示唆

\section{される.}

術前後の聴力レベルと語音聴取閾値を比較す ると，パッチテストで聴力の改善した連鎖正常 群では術後聴カレベル, 語音聴取閾値ともに改 善した.これらの症例ではすべてが I 型手術に なって括り，パッチテストの結果で病変や術式 の予測あるいは術後聴力の推測が可能である.

一方，パッチテストで聴力の改善しなかった連 鎖離断例でも術後気導聴力レベル, 語音聴取閾 值が改善した。これらの症例はすべてコルメラ III型あるいはコルメラ型手術であり，パッチテ ストでやはり病変や術式の予測が可能である.

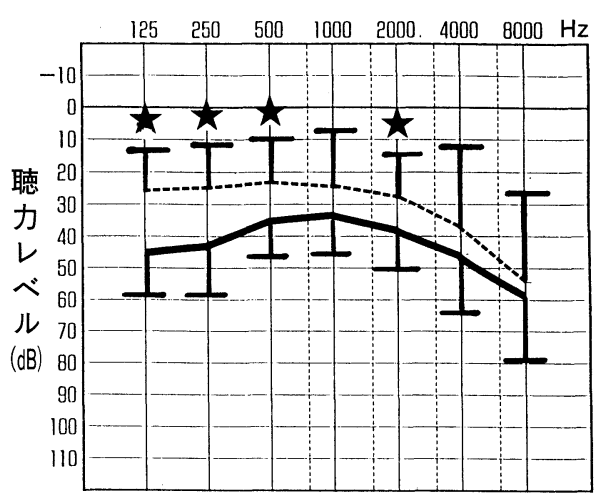

周 波 数 $\mathrm{Hz}$

A. 連鎖正常群

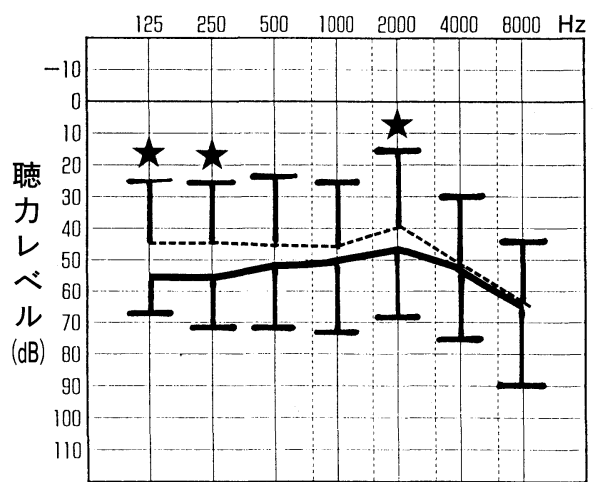

周 波数 $\mathrm{Hz}$

B. 固着群

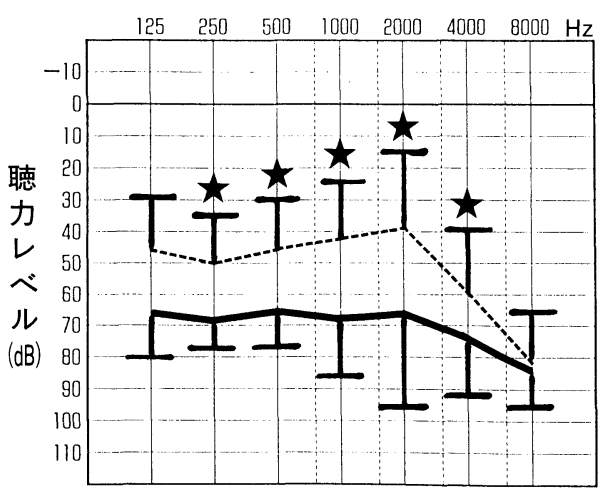

周 波数 $\mathrm{Hz}$

C. 離断群

図 3 各群の術前後の周波数別気導聴力レベルの平均値と標準偏差 実線はパッチ前，点線はパッチ後を示す。 れは術前後で有意な差を認めた場合を示す． 
しかも, 術後聴力も改善することはこれらの症 例でコルメラ而型あるいはコルメラ型手術を選 択することが妥当であることを示唆する。これ に対して, 固着例の術後聴力は一定ではない。 これは固着の程度が症例により様々であり, 手 術による固着の改善も様々であることが関係し ていると考えられる。また固着例に和忷るI型 あるいはコルメラ III型手術の適応の基準が一定 でないことも術後の聴力経過に影響を与えると 推測される.この点に関してはさらに検討する 必要があると思われる.

以上のようにパッチテストの評価を純音聴力 レベルだけでなく, 語音聴力を加えて行ら事で 耳小骨病変が推測できるばかりでなく，I 型め るいはコルメラ正型手術の術式を術前に知るこ とが期待でさる．従って，パッチテストの評価 には純音聴力検査だけでなく語音聴力検査を共 に行うことが望ましい。

\section{まとめ}

1 ）鼓室形成術を行った慢性穿孔性中耳炎 80 耳のパッチテスト前後および術前後の純音聴力 レベルと語音聴取閾値を比較検討した。

2 ）耳小骨連鎖に異常のない症例ではパッチ とよって純音聴力レベル执よび語音聴取閾值と もに改善した。

3 ) 耳小骨に固着病変のある症例ではパッチ によって低中音域で純音聴力レベルの改善を認 めたが，語音聴取閾値の改善は認められなかっ た。

4 ）耳小骨に離断病変がある症例ではパッチ によって純音聴力レベル, 語音聴取閾值ともに 有意な改善は認められなかった。
5 ）耳小骨連鎖に異常がなかった症例および 離断病変のあった症例では, 純音聴力レベルお よび語音聴取閾值ともに術後有意な改善が認め られた，一方, 固着病変のある症例では低音域 の純音聴力レベルで低音域に改善を認めたが, 語音聴取閾值は改善が認められなかった。

6 ）パッチテストの評価を純音聴力レベルだ けでなく, 語音聴力を加えて行ら事で耳小骨病 変が推測できるばかりでなく, 術式を術前に知 ることが期待でき，パッチテストの評価には純 音聴力検查だけでなく語音聴力検査を共に行う ことが望ましいと考えられた。

\section{文献}

1）鈴木淳一：慢性中耳炎(および滲出性中耳炎)の 聴力. 伝音難聴へのアプローチ. 53〜 54頁, 篠 原出版, 東京, 1983.

2) 中溝宗永, 八木聰明，青木秀治，他：パッチテ ストの適応と判定基準について。臨床耳科 15 ： $2 ; 29 \sim 33,1988$.

3）小林 謙, 佐久間文子, 石田祐子, 他: 鼓室形 成術前後の語音聴力検査. 耳鼻臨床 $82: 15 \sim 20$, 1989.

4）相原康孝, 小林 謙, 佐久間文子, 他 : 鼓室形 成術後の語音聴力検査一術後 1 年目に括ける 検討一. 耳鼻臨床 84：901～905, 1991.

5）杉山貴志子，瀧本 勲，石神寬通，他：パッチ テストと手術所見との比較検討.臨床耳科 11 ： 266 267, 1984.

$$
\left.\begin{array}{l}
\text { 原稿受付 : 平成 } 3 \text { 年 } 8 \text { 月 } 26 \text { 日 } \\
\text { 原稿採択 : 平成 } 3 \text { 年 } 9 \text { 月 } 16 \text { 日 } \\
\text { 別刷請求先 : 小林 謙 } \\
\text { 个101 東京都千代田区神田淡路町2-25) } \\
\text { 神尾記念病院耳鼻咽喉科 }
\end{array}\right)
$$

